\title{
Error re-opens 'scientific' whaling debate
}

London. The leaking of a confidential paper questioning Norway's official count of minke whales in the North Atlantic has reopened the debate about its methods of calculating whale stocks, and led to renewed calls from environmentalists for a halt to this year's planned whale hunt.

But the paper, which found three separate errors in the software used to estimate minke whales, seems unlikely to persuade the Norwegians to lower their estimates from the present figure of about $86,700-$ or to stop the hunt from going ahead. One Norwegian researcher describes the new information, which suggests a lower figure of 60,000 , as "relatively minor" and unlikely to have any impact on the country's whaling programme.

The leaked paper was written by Jon Helgeland and Gudmund Høst from the Norwegian Computing Centre and Tore Schweder from the University of Oslo, and was presented to a meeting of the International Whaling Commission (IWC)'s Scientific Committee in January.

The two scientists say that the main effect of correcting the errors they discovered has been to increase the scaling factor employed to allow for whales not seen during sighting surveys. Final whale estimates are arrived at by dividing whale sightings by this factor. A higher factor results in lower whale estimates; a re-run of the computer program with the errors corrected showed a doubling of the factor from previous estimates.

The paper, which was leaked to the press without the scientists' knowledge, is the sec- ond such document to question Norway's estimates of the number of minke whales. Last year, Justin Cook of the World Conservation Union, a member of the IWC's Scientific Committee, was asked to validate Norway's whale estimates by running the Norwegian programme independently, came up with a figure of 53,000 .

Norway has consistently refused to adhere to an IWC moratorium on hunting minke whales. Norwegian scientists say a total whale count in excess of 86,000 justifies a limited whaling programme - they have set a quota of 301 whales each season - and will not affect the overall whale population.

Greenpeace has demanded that the Norwegian government call off this year's whale hunt in the light of the new findings. "Norway's science is now exposed as a sham," says spokeswoman Alison Ross. "Norway has duped the IWC by claiming its whaling was justified by science. It must now cancel its hunt. The time for killing whales whilst fiddling the figures is over."

But Lars Walløe, scientific adviser on whaling to the Norwegian government, says that Norway has no intention of cancelling the hunt, which is scheduled to begin on 2 May - a month before the IWC's next annual meeting. Describing the software errors as "not grievous or serious", he says that the cumulative effect on whale estimates would be small.

Walløe also rejects suggestions of cracks in the Norwegian scientific consensus over whale estimates. He points out that the leaked document was not the only paper

\section{IMAGE UNAVAILABLE FOR COPYRIGHT REASONS}

\section{Minke whales: one fewer to count.}

presented at the meeting.

According to Walløe, a figure of 87,000 minke whales is still on the low side, as calculations do not include recent "improvements" to the figures. Minke whales in the seas off the west coast of Scotland, in the Irish Sea and to the west of Ireland are not included in a recent sighting survey, he added. A 'worst-case scenario', he said, would put Norway's minke whale count at 70,000 .

Ehsan Masood

\section{Australia's CSIRO is urged to turn back to the future}

Sydney. An internal report prepared by Australia's largest research organization, the Commonwealth Scientific and Industrial Research Organization (CSIRO), has recommended the abolition of a system introduced less than ten years ago, grouping its research divisions into separate 'institutes'.

A special committee appointed by CSIRO's board has also suggested that eight of its most senior positions be abolished, and that the organization return roughly to its old structure, under which each research division reported directly to central office.

The new structure would, it suggests, allow CSIRO to become more flexible and responsive to the needs of its customers mainly industrial bodies. At the same time, rather than having a single senior officer at the head of the organization, the committee suggests it should be run by a small management team made up of a chief executive and five other senior executives.

The report of the committee, which included two board members, comes shortly after scathing criticism of CSIRO manage- ment from a bipartisan Senate parliamentary committee. After reviewing evidence from scientists in the organization, the Senate committee concluded in a report published last December that the organization was over-managed and that research was being adversely affected (see Nature 372, 585; 1994)

But CSIRO's acting chief executive, Roy Green, denies that the latest report is connected with the findings of the parliamentary committee. He says CSIRO's internal committee was looking at the organization long before the Senate committee started work. The management committee, he adds, feels that the institute structure has worked well, even if it is no longer appropriate. "The committee's findings in no way reflect anything the Senate said," says Green.

The CSIRO institutes were set up in 1986, each constituting a grouping of divisions with broadly similar research areas, such as the Sydney-based Institute of Animal Production and Processing. They were intended to promote collaboration between divisions with similar interests.

But according to the Senate committee at least, the plan has not worked out. On the evidence of its report, which strongly criticized the role of the institutes, their main function appears to have been to generate "a vast amount of paperwork without clear and worthwhile objectives".

Based on submissions from CSIRO scientists, the committee also described the organization's board as "ineffectual" and criticized the role of its chief executive, John Stocker. Stocker left the organization in March at the end of his five-year contract, and CSIRO is now searching for a new chief executive. The position has been advertised internationally, but the board has not indicated when it is likely to make a final choice to the full position.

Green says CSIRO is prepared to listen to comments on the committee's conclusions from its own scientists, but that it will be up to the incoming chief executive to decide which changes will be introduced.

Mark Lawson 